\title{
The Importance of Generating Funding for The Waqf Development in Pondok Institutions
}

Farahdina Fazial, Salimah Yahaya, Che Khadijah Hamid, Surita Hartini Mat Hassan, Sakinatul Raadiyah Abdullah

To Link this Article: http://dx.doi.org/10.6007/IJARBSS/v11-i4/9750

DOI:10.6007/IJARBSS/v11-i4/9750

Received: 10 February 2021, Revised: 15 March 2021, Accepted: 31 March 2021

Published Online: 24 April 2021

In-Text Citation: (Fazial et al., 2021)

To Cite this Article: Fazial, F., Yahaya, S., Hamid, C. K., Hassan, S. H. M., \& Abdullah, S. R. (2021). The Importance of Generating Funding for The Waqf Development in Pondok Institutions. International Journal of Academic Research in Business and Social Sciences, 11(4), 965-972.

Copyright: (c) 2021 The Author(s)

Published by Human Resource Management Academic Research Society (www.hrmars.com)

This article is published under the Creative Commons Attribution (CC BY 4.0) license. Anyone may reproduce, distribute, translate and create derivative works of this article (for both commercial and non-commercial purposes), subject to full attribution to the original publication and authors. The full terms of this license may be seen at: http://creativecommons.org/licences/by/4.0/legalcode

Vol. 11, No. 4, 2021, Pg. 965 - 972

Full Terms \& Conditions of access and use can be found at http://hrmars.com/index.php/pages/detail/publication-ethics 


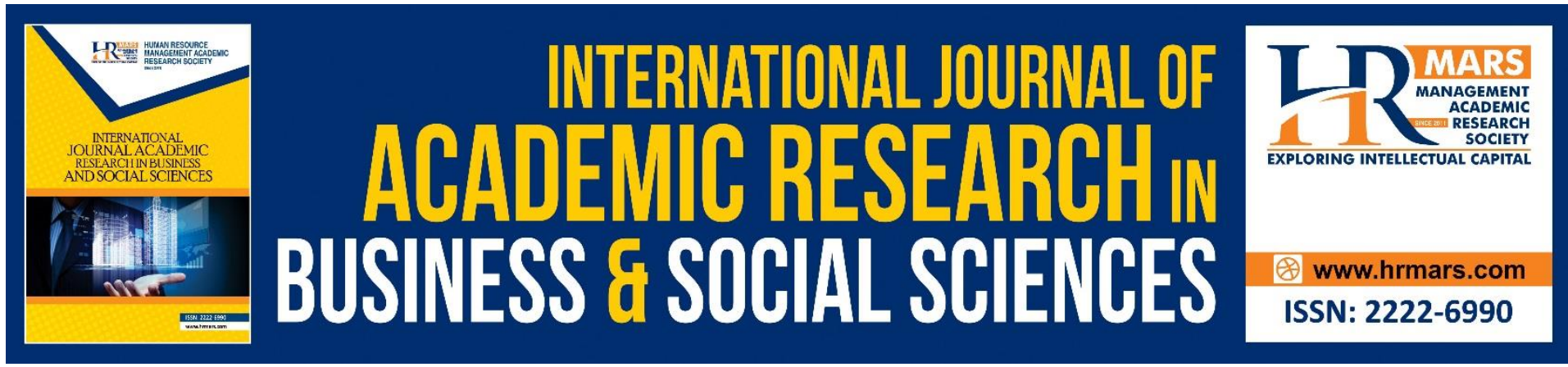

\title{
The Importance of Generating Funding for The Waqf Development in Pondok Institutions
}

\author{
Farahdina Fazial \\ University Teknologi MARA Cawangan Kedah, Malaysia. \\ Email: farahdinafazial@uitm.edu.my
}

Salimah Yahaya, Che Khadijah Hamid

University Teknologi MARA Cawangan TerengganuTerengganu, Malaysia.

\section{Surita Hartini Mat Hassan, Sakinatul Raadiyah Abdullah University Teknologi MARA Cawangan Pahang, Pahang, Malaysia.}

\begin{abstract}
Pondok institutions are the earliest education institution in Malaya. Some of the state's famous for pondok institution education are Kelantan, Terengganu, Kedah and Perak. Most of pondok institutions in Malaysia depend on the people's contributions in the form of donation, waqf, infaq and zakat to continue to operate. Waqf is seen as an instrument that can be used to generate the funding of the pondok. Most of the pondok are the earliest waqf education institution in the Archipelago. Thus, this study focuses on the significance of the funding generation for the waqf development in pondok institutions. This is a qualitative study that uses the primary data through an in-depth interview done on several informants involved in the waqf funding generation in pondok institutions. Secondary data was obtained through document analysis. The outcome of the study establishes that there are four aspects of significance of the funding generation namely consolidation in terms of the financial and economic aspects of the pondok, its improved facilities and infrastructure, increased skills of the members of the pondok in the field of entrepreneurship also the benefits from the social aspect.
\end{abstract}

Keywords: Generating Funds, Waqf Development, Pondok Institution

Introduction

Generally speaking, the pondok institutions in Malaysia are the earliest waqf education institutions in the Malay Archipelago. Even so, the change made to the education system has led to a lot of pondok institutions being converted to Sekolah Agama Rakyat (SAR) and Sekolah Agama Bantuan Kerajaan (SABK). The financial factor also stands in the way as the main factor as to why many pondok schools are closed down- they are simply unable to bear the cost of operation and to fund the development of the pondok schools. 
The waqf instrument is seen to be able to help the institutions in generating the fund that can benefit the waqf development. This is due to the fact that waqf has been one of the economic and social development for Muslims. Ages ago, the waqf generation plays a great role in equipping the society with various facilities, like school, mosque, education, healthcare, and so on. In the education domain, waqf is seen as an approach that helps collect the fund at the expense of education management and development. There has been evidence of the role of waqf in the education aspect through the success demonstrated by previous education institutions such as al-Qarawiyyin University, Nizamiyyah Madrasah and A-Azhar University. Apart from that, there is a lot of higher learning institutions in Malaysia that have chosen waqf as one of their instruments in generating the economy of the universities.

The generating funding of waqf development has indirectly formed a concept of a waqf asset sustainability that is efficient. The stakeholders are responsible in ensuring that the waqf asset can be generated and developed, in line with the initial intention of the donor who hands over his asset to the path of Allah SWT to reap the reward throughout his life (Sulaiman, Hasan \& Muhammad, 2016). This innovative and creative way not only help fund the pondok institutions continuously but they will also add to the institutions' assets.

This paper work begins with the discussion about past literature. This is then followed by the discussion about the study methodology, previous works on the generation and funding of waqf, an analysis of the importance of the waqf funding generation in pondok institutions and it ends with the impending conclusion.

\section{Past Studies}

Studies on earliest waqf education institutions were carried out by Ahmad Zaki Abd Latif et al. (2008) Abd Rahman (2009) and Sayyin (2011). Past studies related to waqf and higher education institutions were done by Ismail and Abd Hamid (2014); Abdul Latiff \& Hassan (2005); Hardaker \& Sabki (2011).

The studies that focus on waqf and the funding of the IPT (HLE) development have been carried out by various researchers such as Ahmad Shukor (2013); Ali \& Wahid, (2014); Moh Salleh (2018); Othman, et al., (2018); Hassan and Ahmad (2018); Mujani, Mohd Taib, Rifin \& Khalid (2018). Through these studies, they are unanimous to say that waqf plays a major role in funding the development and activities of the university through investment and waqf fund generation methods.

The study on waqf asset development has been done by Abd Rahman (2009). The waqf can serve as the medium of wealth distribution to the society as a whole in eradicating poverty and it can be the channel to enhance the socio-economic services like education, health, orphan care-taking, mosque construction and so on. This is similar to the studies by Wan Yon, Abdul Latif and Bahrom (2008) who opined that the waqf asset developed can assuage the load borne by the government, create social justice and develop Islamic da'wah. Studies with regard to the priorities in developing waqf have been done by Pitchay, Ahamed Mydin, and Saleem (2014).

The studies done by Abd Rahman (2009); Mohd Ali, Ahmad, \& Ahmad Mahdzan (2018) focus on the requirements for the recipients of the waqf when the development takes place. Waqf asset development and generation are important to preserve the society's welfare through 
the provision of physical infrastructure and services in religious affairs, education, health, agriculture, and commercial and looking after the welfare of the unfortunate people.

The sustainability of waqf asset can be implemented through a waqf asset development funding method. Thus, the method must be made productive so that the benefit can be channelled to the recipients in the best way possible. The development of a sustainable waqf asset can curb the asset from going to waste for the Muslims (Omar \& Abd Rahman, 2015). For the implementation, there are at least three involved parties in this process namely the administrator of the waqf institution, the donor and the manager of the waqf fund - this is to ensure that the sustainability of the waqf development can be more dynamic.

\section{Study Methodology}

This study involves two methods of data collection namely the primary and secondary data. The primary data is obtained through an in-depth interview on four categories of informants namely the governor of the institutions, the administrators of the pondok, the expert representing the waqf and the governor. In this paper work, the governor is labeled with the code stipulated (M001-M012), experts of waqf (PW001-PW002), the administrators of the pondok (PP001) and the governor (PM001) to get information regarding the use of the waqf as the instrument of the fund generation. The secondary data was obtained using previous studies and documents. The data in this paper work will be analyzed using the application called Atlas t.i versi 8 (AV8).

\section{Study Analysis}

The generation of waqf in pondok institutions not only benefits the institution itself, but also on the society and the development of Islam. Based on the interview done, the four aspects of significance of the funding for the pondok institutions have been identified and they are consolidation in terms of the pondok's financial and economic aspects, improved infrastructure and facilities, enhanced skills of the members in entrepreneurship and benefit from the social aspect. We can refer to the finding in Table 1.

\begin{tabular}{|l|l|}
\hline \multirow{2}{*}{$\begin{array}{l}\text { The Importance of Generating } \\
\text { Funding for The Development of } \\
\text { Pondok Institutions }\end{array}$} & $\begin{array}{l}\text { Consolidation in terms of financial } \\
\text { and economic aspects of the } \\
\text { institution }\end{array}$ \\
\cline { 2 - 2 } & $\begin{array}{l}\text { Improved facilities and infrastructure } \\
\text { Enhanced skills of the members of the } \\
\text { pondok in entrepreneurship }\end{array}$ \\
\cline { 2 - 2 } & Benefit from the social aspect \\
\hline
\end{tabular}

Table 1: The Importance of Generating Funding for The Development of Pondok Institutions

Firstly, in terms of finance, the waqf development funding in a pondok institution will not only increase the economy of the pondok but it can also solidify the financial strength so that they will not rely totally on the contributions of the society. The pondok institutions also do not have to anticipate any financial contributions and donations from the society and the government to fund the development continuously to ensure their continuous operations. However, the success of the generation of waqf in a pondok institution depends on the ability, capability and the determination of the management to make sure that the planned development can work smoothly. Looking at the significance of the waqf generation in pondok institutions, PM001 stated that the impact of the generation is based on the following 
hadith:

From Hakim bin Hiram radliallahu'anhu from the Prophet SAW: "The hands above are better than the hands below, so you start from those under your care and the best donation is from those who have enough for themselves. So, to anyone who tries to sustain himself, Allah will protect him and those who makes an effort to sustain himself, Allah will accommodate for him" (Hadith Riwayat Bukhari, No: 1338)

Referring to the above hadith, it can be concluded that givers are better than beggars. Although the act of asking for money is prohibited but it would be better for a pondok institution to have its own capability in generating its own fund and able to help the society through the money collected, rather than simply hoping and relying on donations and contributions.

Other than that, there are still a lot of pondok institutions that do not make productive waqf asset contributed by the society. These waqf assets are not used for activities that do not give any return and lucrative outcome to members of the pondok and the society. In other words, pondok institutions only receive waqf fund contributions and they do not make any effort in generating money through the waqf they receive. This is in line with the statement of Zakaria Bahari (2012), most of the waqf management only hopes for the soceity's contributions to manage the asset and lack the initiative in increasing the production of the asset by means of business or economy.

The funding of the development through waqf does not only help expand the economy of the pondok, but indirectly it increases the confidence of the people in pondok institutions. This is because pondok institutions that only seek to receive waqf fund without making any effort to develop their own economy will simultaneously show its incapability in expanding the fund received. The determination of the institution in generating and developing its own economy has indirectly boost the faith of the community in continuing to help the pondok.

For PP001 and PA002, pondok institutions are able to develop the waqf asset and contribute to the education of the locals as a whole. In Indonesia, Pondok Moden Daarusslam Gontor (PMDG), can influence and engage the society in pondok activities especially in terms of the economy, industry and so on. PMDG also has its own specific fund to send their students abroad and then they will continue to serve at Gontor. This is similar to the visit of PM001, namely Pondok Nurul Iman Bogor that also proves that the pondok is able to generate its own funding for the sustainability of its economy and it also involves students in the effort to develop it.

Secondly, waqf generation can help improve the facilities and the general welfare. This refers to the history of waqf during the Ottoman Turks era, where waqf had helped develop various infrastructures including those in the field of education (Saduman \& Aysun, 2009). If the economic generation is done in a systematic way, pondok institutions can be competitive with other religious schools. Pondok institutions will be an alternative, not merely as a religious institution that stresses on the aspect of the Hereafter, but also consistent with other forms of development. 
Other than that, pondok education is also seen to be more systematic and more developed as it is able to prepare a more conducive and systematic learning infrastructures, able to add the number of teachers, increase salary and allowances at the same time can improve their studies. Some of the factors why most teachers at pondok institutions cannot last long is due to the fact that they are paid meagre allowances and this will make it difficult for them serve. As the repercussion, the studies will also be impacted as there is not enough teachers to teach.

Thirdly, the economic generation of pondok through waqf not only trains the management of the pondok in managing the fund of the pondok in the best way possible but it also trains students in the world of entrepreneurship. The exposure of students in the business world indirectly educates students to become pious entrepreneurs. The application of skill knowledge implemented can train students in the fields of business and human resources. The pondok institutions that equip students with religious knowledge are added with certain skills and this will produce students that can give benefit in this world and in the hereafter.

Other than that, through the method of waqf generation at the pondok institutions, pondok students are not only the people that master their religious knowledge alone but they are also trained to be traders, entrepreneurs and business people especially in the business field. To encourage students, it should be the grounds for students to learn the basic entrepreneurship knowledge and automatically help the pondok to generate its economy through waqf. Among the strategies carried out by PMDSG and Pondok Nurul Iman, Bogor in Indonesia in training students in the field are by involving them in entrepreneurship and giving them the responsibility to manage the projects carried out by the pondok.

\begin{abstract}
"The pondok have mandated its students who have finished their studies to manage the projects under pondok. After they have completed their studies, they are asked to serve and manage the projects of generating the fund for two years before they can go back to their hometowns. These students are supervised by the teacher to ensure that the business is going smoothly." (PM001)
\end{abstract}

The impelling generation of the waqf fund in pondok institutions has indirectly produced Muslim entrepreneurs and prepared multiple job opportunities to the locals. That said, the economic investment and expansion done must be monitored by experts who have the credibility and are professional in related field so that the waqf done by the can give an ongoing benefit to the members of the pondok and the local people.

Fourth, the waqf development funding also gives benefit in terms of the social aspect. This is proven through the generation of waqf carried out by Al-Azhar University in Egypt that has given a major contribution to its students. Students can enjoy learning free throughout their studies in the university and this will indirectly lessen the burden of the students as they are in the process of seeking for knowledge. Mohammad Aslam \& Wan Mohd Dhaiyudeen (2015) stated that the development and the administration of Al-Azhar University are still funded by the waqf fund until today. The concept of educational waqf raised is a mark of equality in seeking for knowledge and in lessening the financial burden faced by the students. 
The same opinion is raised by M004 who stated that the method of generating the waqf assets is also adopted in pondok institutions in Thailand. The waqf lands are cultivated through the rubber plantation method. The outcome from the plantation can be channeled to the madrassa and used to help students in need, also the orphans. The madrassa also imposes low fees to the students. The impact from this is that the pondok's economy is not only better, but it attracts more and more students to come. This is admitted by $\mathrm{M} 002$ who stated that the aim of the generation of the pondok development is not only from the aspect of the pondok development alone but it also aims to assist students by charging them low fees and even free of charge, as done by the Al-Azhar University and several other education institutions. The pondok also plans to use the outcome from the generation of fund to help rebuild pondok and schools.

Based on the discussion above, it is clear that waqf plays a very significant role as an instrument of the development fund in pondok institutions. Waqf development funding helps elevate the status of the socio-economy. Such a development in the field of education must be given due attention and empowered to produce more quality and credible Muslim scholars, entrepreneurs and pondok institutions in years to come. The sustainability of the waqf to fund the development in pondok institutions must be revised in detail by proposing various approaches to ensure that the waqf in pondok institutions can be sustainable in the long run.

\section{Conclusion}

The waqf generation in pondok institutions is very important to ensure that these institutions are sustainable. This is due to the fact that pondok institutions must make an effort to improve the economy and consolidate the financial system without so much dependency on the government and the society. This not only indirectly exposes pondok institutions to entrepreneurship and business, but it can also spread further the da'wah efforts made.

\section{References}

Abdul Latiff, A. Z., Ramli, A. H., Ismail, C. Z., Sulaiman, K., \& Abdul Hamid, N. (2005). Potensi wakaf ke arah kemajuan pendidikan Islam di Malaysia, In. Abdul Halim Ramli \& Ahmad Che Yaacob (Eds.), Islam Hadhari: Pengukuhan institusi baitulmal dan wakaf di Malaysia (hlmn.127-138), Selangor: Pusat Penerbitan Universiti (UPENA), Uitm.

Abd Latiff, A. Z., Ramli, A. H., Ismail, C. Z., Sulaiman, K., \& Daud, M. N. (2008). Pengurusan harta wakaf dan potensinya ke arah kemajuan pendidikan umat Islam di Malaysia. Jurnal Pengurusan JAWHAR, 2 (2).

Ab Rahman, A. (2009). Peranan wakaf dalam pembangunan ekonomi umat Islam. Jurnal Syariah,17(1), 113-152.

Shukor, A. S. A (2013). Potensi wakaf pendidikan tinggi di Malaysia. Unpublished Master Thesis. Universiti Sains Malaysia, Pulau Pinang.

Ali, N. M., Ahmad, R., \& Mahdzan, N. S. A. (2018). Waqf Land Development in Malaysia: Study on the Needs of the Beneficiaries. Advanced Science Letters, 24(7), 5132-5135.

Hardaker, G., \& Sabki, A (2011). Innovative practice: An insight into Islamic pedagogy at the University of al-Qarawiyyin. Multicultural Education \& Technology Journal, 6 (2).

Hasan, H., \& Ahmad, I. (2018). Determinants of higher education in Islamic endowment (Waqf) attributes among Muslims in Malaysia. Journal of Islamic, Social, Economics and Development, 3(12). 
Hydzulkifli \& Ab Rahman, A. (2015). Pembiayaan pembangunan harta wakaf menggunakan sukuk. Universiti Malaya.

Mujani, W. K., Taib, M. M., Rifin, M. K. I., \& Khalid, K. A. T. (2018). The history of the development of higher education waqf in Malaysia. International Journal of Civil Engineering and Technology (IJCIET), 9(3), 549-557.

Pitchay, A. A., Meera, A. K. M., \& Saleem, M. Y. (2014). Priority of waqf development among malaysian cash waqf donors: An AHP approach. Journal of Islamic Finance, 3(1).

Ramli, R. N. A. R., \& Abd Hamid, N. A. (2014). Kelestarian wakaf dalam membangunkan institusi pendidikan: Kajian Awal. In Kertas kerja yang dibentangkan dalam International Conference on Postgraduate Research (pp. 1-2).

Salleh, M. F. M. (2019). Endowment Fund (Waqaf) as an Answer to Increasing Cost in Managing Higher Institutions. In 5th Annual International Conference on Management Research (AICMaR 2018), 71-74. Atlantis Press.

Sayin, B., Abd Manan, S. K., Ali, A., \& Salahudi, S. (2011). Kefahaman warga uitm di Selangor, Perak dan Negeri Sembilan terhadap konsep wakaf, dlm. Baharuddin Sayyin (Eds), Isuisu semasa mengenai wakaf Selangor (1-27), Shah Alam: Pusat Penerbitan Universiti (UPENA), Universiti Teknologi Malaysia

Sulaiman, S., Hasan, A., \& Muhammad, A. A. (2016). Pembangunan dan pelaburan lestari harta wakaf dari perspektif Islam. Satu tinjauan. Jurnal Kanun, 28 (1).

Wan Yon, W. A., Abdul Latif, M. S., \& Bahrom, H. (2008). Makanisme wakaf: Gagasan awal terhadap pembangunan dan pembiayaan pusat penyelidikan dan perkembangan Islam Borneo. Jurnal Pengurusan JAWHAR, 2 (2). 